\title{
Capital Markets and Financial Politics: Preferences and Institutions
}

\section{Citation}

Mark J. Roe, Capital Markets and Financial Politics: Preferences and Institutions, 7 The Oxford Handbook of Capitalism (2012).

\section{Published Version}

10.1093/oxfordhb/9780195391176.013.0004

\section{Permanent link}

http://nrs.harvard.edu/urn-3:HUL.InstRepos:32136184

\section{Terms of Use}

This article was downloaded from Harvard University's DASH repository, and is made available under the terms and conditions applicable to Open Access Policy Articles, as set forth at http:// nrs.harvard.edu/urn-3:HUL.InstRepos:dash.current.terms-of-use\#OAP

\section{Share Your Story}

The Harvard community has made this article openly available.

Please share how this access benefits you. Submit a story.

Accessibility 
ISSN 1936-5349 (print)

ISSN 1936-5357 (online)

\title{
HARVARD
}

JOHN M. OLIN CENTER FOR LAW, ECONOMICS, AND BUSINESS

\section{CAPITAL MARKETS AND FINANCIAL POLITICS: PREFERENCES AND INSTITUTIONS}

\author{
Mark J. Roe
}

Discussion Paper No. 699

$06 / 2011$

Harvard Law School

Cambridge, MA 02138

This paper can be downloaded without charge from:

The Harvard John M. Olin Discussion Paper Series:

http://www.law.harvard.edu/programs/olin_center/

This paper is also a discussion paper of the

John M. Olin Center’s Program on Corporate Governance. 
JEL Classifications: G18, G3, K11, K22,

M16, N20, O16, O43, P16, P51

Oxford Handbook on Capitalism, forthcoming 2011

\title{
Capital Markets and Financial Politics: Preferences and Institutions
}

\author{
Mark J. Roe ${ }^{1}$
}

\begin{abstract}
For capital markets to function, political institutions must support capitalism in general and the capitalism of financial markets in particular. Yet capital markets' shape, support, and extent are often contested in the polity. Powerful elements - from politicians to mass popular movements - have reason to change, co-opt, and remove value from capital markets. And players in capital markets have reason to seek rules that favor their own capital channels over those of others. How these contests are settled deeply affects the form, the extent, and the effectiveness of capital markets. And investigation of the primary political economy forces shaping capital markets can point us to a more general aspect of economic, political, and legal institutions. Much important work has been done in recent decades on the vitality of institutions. Less well emphasized thus far is that widely-shared, deeply-held preferences, often arising from current interests and opinions, can at times sweep away prior institutions or, less dramatically but more often, sharply alter or replace them. When they do so, old institutions can be replaced by new ones, or strongly modified. Preferences can at crucial times trump institutions, and how the two interact is well-illustrated by the political economy of capital markets.
\end{abstract}

${ }^{1}$ Professor, Harvard Law School 



\title{
Capital Markets ANd Financial Politics: PREFERENCES AND INSTITUTIONS
}

\author{
Mark J. Roe
}

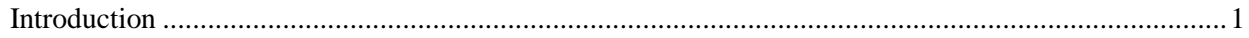

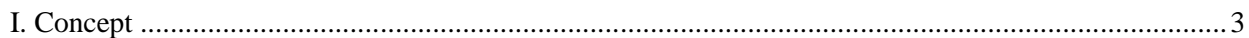

A. Capital Markets’ Dependence on Political Institutions ............................................................ 3

B. The Interests that Support, or Denigrate, Capital Markets ............................................................ 3

II. Capital Markets and Financial Politics in the Developed World .................................................. 3

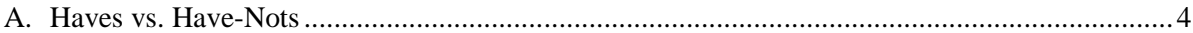

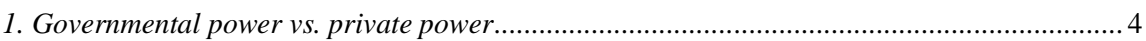

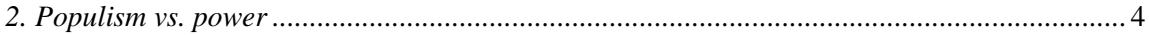

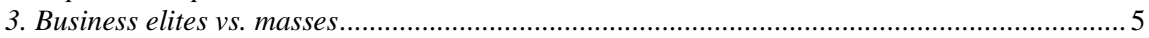

4. Social democracy vs. capital markets.................................................................................. 5

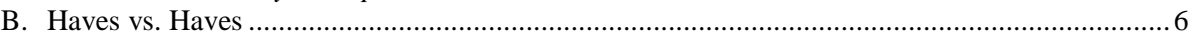

1. Capital markets' internal fissures, especially that of banks vs. stock market capitalism........... 6

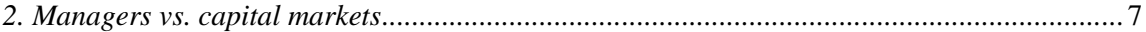

3. Controlling shareholders vs. capital markets............................................................... 8

III. Capital Markets and Financial Politics in the Developing World ...................................................... 8

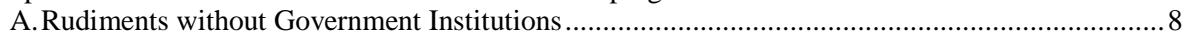

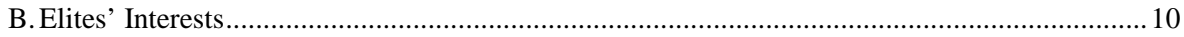

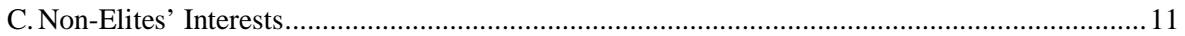

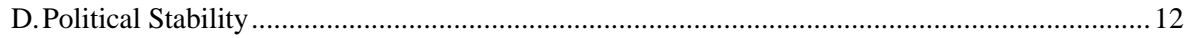

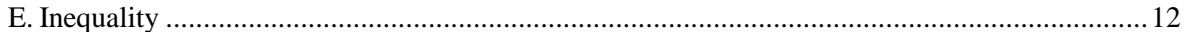

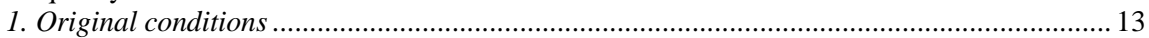

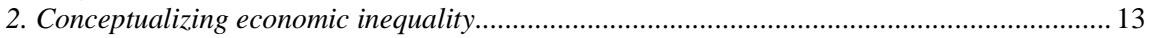

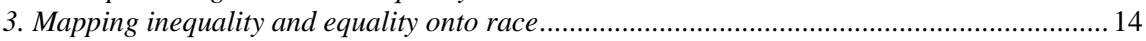

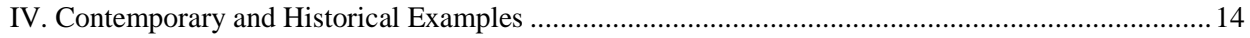

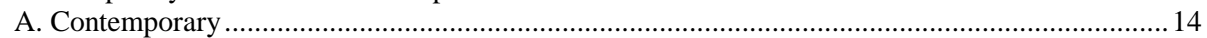

1. Labor in Europe ……....................................................................................................... 14

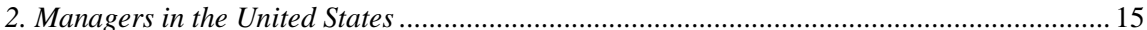

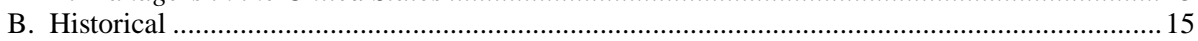

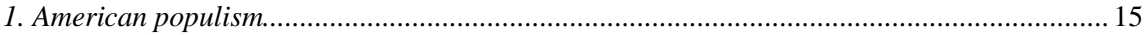

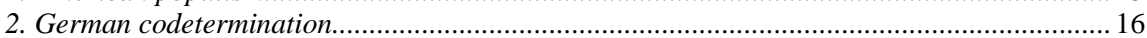

V. Preference Aggregation and Combinatorics................................................................................ 17

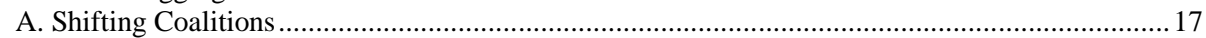

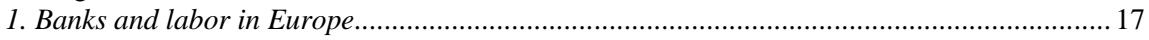

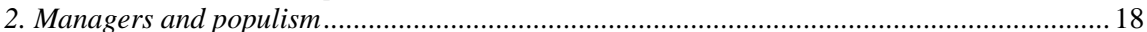

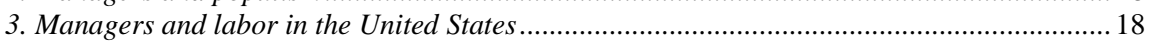

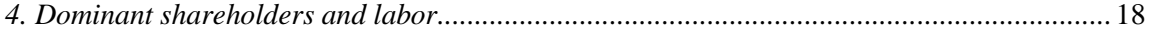

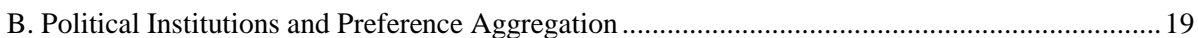

1. Parliamentary vs. presidential systems: proportional representation and party-lists ............. 19

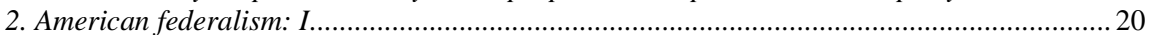

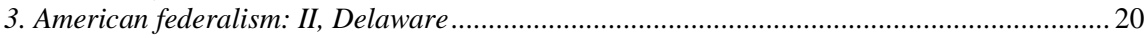

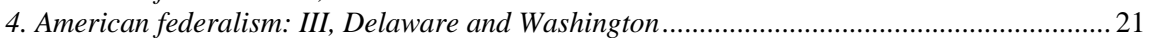

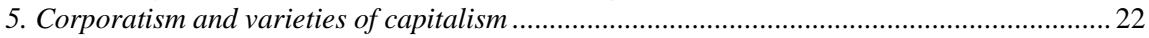

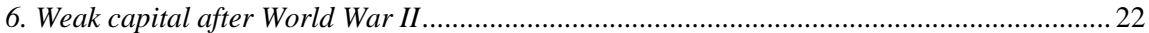

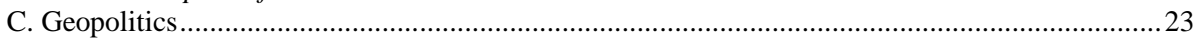

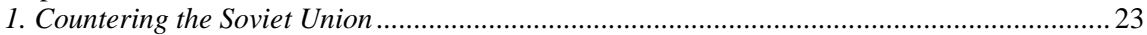

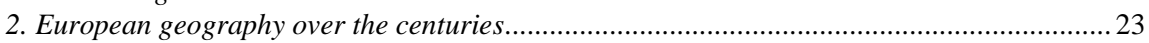

D. Political Change: Rightward and Leftward Shifts over Time .....................................................24

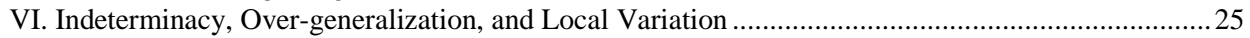

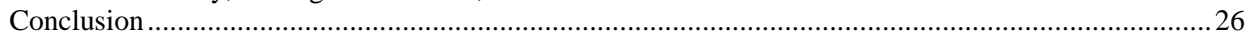





\title{
Capital Markets and Financial Politics: Preferences and Institutions
}

\author{
(C) 2011. Mark J. Roe* All Right Reserved.
}

\section{INTRODUCTION}

For capital markets to function, political institutions must support capitalism in general and the capitalism of financial markets in particular. Yet it's not so obvious how and why political institutions come to support a deep, wide, wellfunctioning capital market, because many interests have reason to undermine the capital market and because the immediate beneficiary of a strong capital market is a minority of wealthy capital-owners. The polity in a functioning democracy must come to see capital markets as benefiting the majority, despite the fact that the benefit is indirect and not always vivid.

Here I outline the main weaknesses in the interaction between political institutions and capitalism, indicate the most common resolution of these weaknesses, and show how the interaction between capital markets and politics has been seen in the academic literature.

Two core categories of problems afflict the interaction between politics and financial markets, both emanating from the fact that capitalism can generate large pools of financial assets whose disposition and use can be contested. The first is that the have-nots, eyeing those assets, may use the political arena to obtain a slice of those assets that they cannot obtain in the economic arena, thereby creating a pernicious contest between the haves and the have-nots, one that burns resources and that needs to be settled or accommodated. How that contest is resolved deeply affects both the shape and extent of the capital market.

The second recurring problem is that the haves - typically the capitalowners themselves, but not always, as managers without capital often have considerable political influence due to the control over assets that they do not themselves formally own - may fight among themselves for rights to those assets. While it is tempting to explain the survival of longstanding financial and corporate structures as resulting from rational optimization of private goals, they are often just as much reactions to conflicts among capital-owners, or mandates from the winners. I will give some examples in the United States of how conflicts among capitalists and their managers largely explain core features of the capital market for the large public firm in the United States. Other examples can be had from Western Europe. Private optimization explanations alone cannot do the job.

Many of the real world's interactions between politics and capitalism are variations of these two fundamental contests, between have and have-nots, and among the haves themselves. And a considerable portion of the academic world's analysis of modern political economy involves variations of these two fundamental problems. 
When we see weak capital markets in a nation, or when we ask why a nation's capital market takes on a particular configuration, we tend to look to efficiency explanations for the result: the country doesn't need securities markets for this or that reason; banks fit best with the production technology then prevailing in that economy; or the country never developed the institutions of investor protection. These are surely relevant to a full explanation. Less wellhighlighted, even today, are that political economy explanations are also core to any full explanation. Look to the dominant political interests and decision-makers in the society - if we do not see strong capital markets, it's often because it's not in the politically decisive players' interest to allow them to be strong. If their interests change, the capital markets' character can also change.

This political explanation is especially likely to be in play in nations that have had little difficulty in building other resilient institutions: particularly for such nations, political support for capital markets is more likely to be a policy choice rather than an issue of institutional capabilities.

Complications abound. Causation is bidirectional; several economic, institutional, and political features are determined simultaneously. Few political features are fully discrete. Most interact, with coalitions and multiple political forces in play. I sketch here the simple stories first, then show several of the interactions, complications, and causation reversals.

Financial markets can be seen as primarily a function of a nation's governing institutions. Considerable progress has been made in economics since North (1990) demonstrated institutions' importance. But institutions interact with preferences and, indeed, widespread deeply-held preferences (presumably emanating from immediate interests and, at times, overall ideologies) can bend, destroy, and build institutions. Here I give more emphasis than is typical to the role of preferences in constructing the institutions of financial markets.

I divide the inquiry along two major dimensions. First, what is the political economy - the interaction between preferences and institutions - of capitalist finance for the nation's haves versus the have-nots? And second, what is the political economy of capitalist finance that divides the nation's haves? Subsidiary to each dimension, I ask how these questions play out in the world's richer nations and how they play out in the world's developing nations. Are there enough commonalities across nations, so that patterns can be discerned?

I also show how this inquiry highlights the importance of attending to the interaction between institutions and preferences. The former has been central in scholarship of the past few decades. Institutions are indeed important — but so are preferences and interests, and these preferences and interests are not always shaped by their institutional environment. What seems sometimes obscured in the literature is that preferences, when sufficiently powerful, can wash institutions away as easily as shacks collapse in a hurricane. That does not happen often outside of severe crisis, but it does happen then. And preferences can then build the institutions that can withstand (some of) the future's fickleness. Today's institutions developed out of the preferences that dominated in the past. And 
tomorrow's institutions may well be as much a function of today's preferences as they are of today's institutions.

\section{CONCEPT}

\section{A. Capital Markets’ Dependence on Political Institutions}

If a nation's polity does not support a capital market, that nation will not have strong capital markets. Examine whether strong capital markets are in the interest of the decisive political actors - or what shape of capital markets best implements their interests - and one is likely to have a primary explanation for the shape and extent of the nation's capital market. The concept is simple, but powerful.

\section{B. The Interests that Support, or Denigrate, Capital Markets}

Capital owners typically have an interest in promoting capital markets and their supporting institutions, but other interests may not. Local interests may oppose centralized financial institutions that move capital. Those with strong human capital could fear that strong capital markets would erode that human capital's value, by forcing more market-oriented change more quickly. Those without financial capital today and with poor prospects of acquiring capital in the future could prefer that the polity take capital from those who have it and use it to benefit those who do not.

Capital is often unevenly distributed in a nation, facilitating conflict between haves and have-nots. Even when income and property are roughly evenly distributed, economic rationality demands aggregation institutions, like banks and securities markets, to achieve operational economies of scale. These aggregations can become vivid in the polity and attract negative attention.

Capital markets are not generic. Banks have an interest in preserving bank financing channels and in weakening securities market channels. Securities dealers and investment bankers have an interest in preserving and expanding securities markets. Dominant owners, such as families traditionally or private equity firms more recently have interests in preserving their privileges. Owners of existing firms want access to cheap capital, but prefer that their competitors not have the same easy access.

Government bureaucracies can be wary of rival power centers in capital markets or, sometimes, wish to promote them as counter-weights to other power centers in their society.

\section{Capital markets and Financial Politics in the DeVeloped WORLD}


Two basic political cleavages organize the inquiry here for developed nations: one, the contest between those who have capital and those who do not, and, two, contests among the owners of capital.

\section{A. Haves vs. Have-Nots}

1. Governmental power vs. private power. The most basic political economy have vs. have-not conflict is between governmental authorities and private sector players who command capital. While not usually seen as a conflict between haves and have-nots, it is indeed such a conflict - as government often seeks to obtain for itself capital that it lacks or to command its private sector use. In extreme form, a non-democratic, dictatorial government could prefer to directly allocate capital itself, stifling the development of a private sector in general, and capital markets in particular, as such markets can become rival power centers in the nation.

Governmental authorities can build, shape, or destroy capital markets, for their own reasons and not as tools of other interests or ideologies. The governmental authorities may wish to denigrate a rival power center, one that could seek to control the government. Governmental authorities could be susceptible to ideologies and beliefs that capital markets will not produce social welfare and that government needs to direct and control capital flows to better produce wealth or justice. Finally, governmental authorities may see government action as the vanguard of economic and social development; in pursuing policies to implement their goals, they can crowd out private capital markets and thereby prevent them from developing nicely.

More standard accounts, which I shall address below, examine how interests can capture government decisionmaking and use captured governmental institutions for the interests' own ends. But the concept differs in this section. Government authorities are themselves an interest, with their own interests and ideology separate from those in the civil, nongovernmental society. Their own direct interests and beliefs can motivate their actions vis-à-vis capital markets. See Douglas (1940: 11, 14) (statement from chair of SEC: people who dominate financial markets have "tremendous power.... Such [people] become virtual governments in the power at their disposal. [Sometimes it is] the dut[y] of government to police them, at times to break them up ... .”); cf. Skocpol (1979).

2. Populism vs. power. Populism can affect financial markets and institutions, often in reaction to financial crises and poor economic results. Popular opinion may seek as much to punish financiers and their institutions as to improve the financial system's functioning, as the two - punishment and improvement could be conflated in the popular mind. When this feature is powerful in politics, it can induce an institutionalization of anti-capital rules and reaction. Then, once institutionalized, interests arise with reason to perpetuate the underlying rules and the resultant arrangements. Thus, even when the popular animus against finance dissipates in more normal political times, the created interests can stymie a return to the previous arrangements. 
3. Business elites vs. masses. Workers could dislike capital and capital markets. Farmers may blame financial markets for their misfortunes as much as bad weather. Each group may have simple redistributional goals, or their thinking and voting may be influenced by envy.

4. Social democracy vs. capital markets. Social democracy played a central role in how capital markets developed in post-World War II Western Europe. By social democracy I mean a nation committed to private property, but where distributional considerations are vital, where labor is typically powerful, and where government action to foster economic equality is central on the political agenda.

For diffuse stock markets to persist, the diffuse capital-owners must see their firms as managed by agents who are sufficiently loyal to shareholders to provide shareholder value. For dominant shareholders to turn their firm over to ownership in liquid stock markets and, hence, to managerial control, they must expect that the net value of the turnover is beneficial. If the benefits of liquidity and professional management are offset by managerial disloyalty, fewer dominant stockholders will turn their firms over to managers than otherwise. For shareholders to count on this managerial loyalty, they need institutions and norms that induce that kind of loyalty. But if a polity will not provide those institutions, or if it denigrates such norms, more shareholder value can be obtained by dominant stockholders keeping control of the firm. Managerial control will not ordinarily appear and will be unstable if it does. Stock markets will not be strong in such nations, because managerial agency costs will be too high and too hard to get to acceptable levels.

Figure 1 illustrates the relationship between labor power (quantified by union and job security rules) and the degree to which large firms have large blockholders. Greater labor power is associated with greater ownership concentration; weaker labor power is associated with more diffuse ownership. Details, sources, and background to the graphic can be found in Roe (2000, 2003).

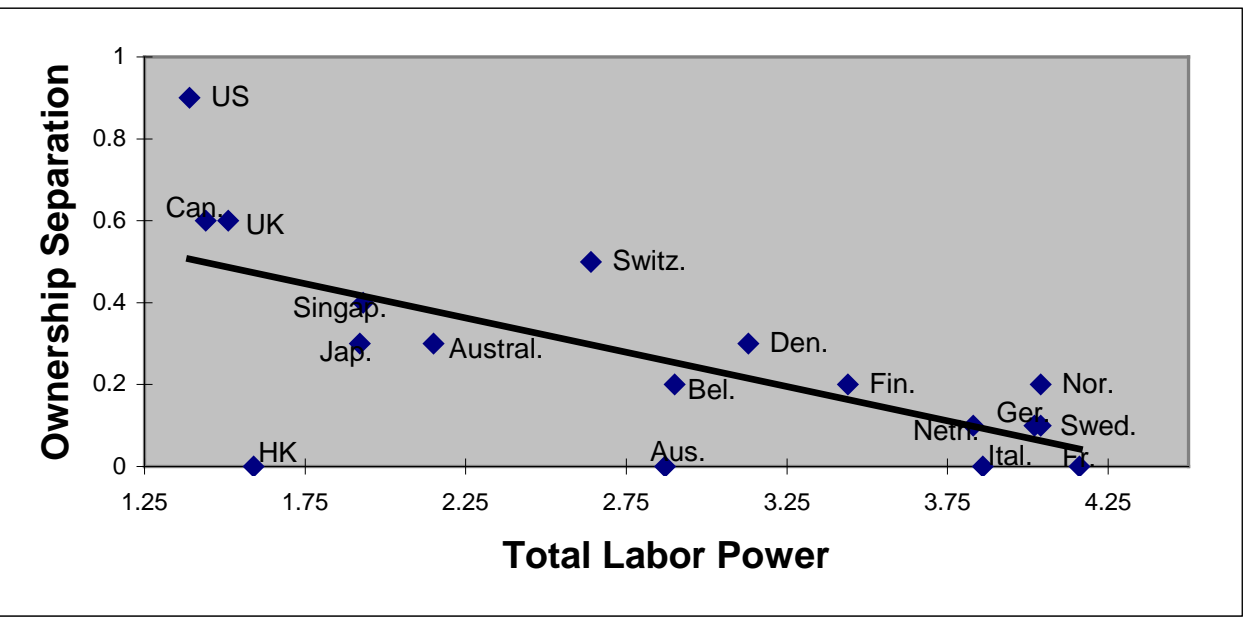

Visible incentive compensation that ties managers to owners may be denigrated in a social democracy more than it is in a more conservative polity. Any 
resulting wealth disparity could especially demoralize lower-level employees and lead them to demand further compensation for themselves. And, as noted above, governmental players can be less willing to provide capital-market-supporting institutions, such as disclosure rules and enforcement, insider trading sanctions, and commercial courts, as the authorities may see these difficulties as disputes among the well-to-do - disputes that the public authorities need not attend to. These costs to controlling managerial agency costs can be particularly severe in social democratic polities.

A considerable literature has developed on the primacy of institutions in property rights protection, which has obvious relevance to protection of capital market investors. While institutions are surely important, the possibility exists that the academic literature is over-sold on institutions now, while under-estimating simple, basic political power. Politicians can mold institutions. Even in the United States, where property rights institutions are typically seen as being as strong as they can be, a Congress that wanted to attack capital markets could do so and do so effectively.

What may well count as much as institutions for the United States is that there is no political will for a frontal assault on American capital markets. And, indeed, recent evidence indicates that right-leaning governments are perceived by property owners to protect their property better than left-leaning ones and that this partisanship dimension dominates institutional characteristics in explaining the degree of perceived property protection. ${ }^{2}$

Those then are the major have vs. have-not breaks affecting capital markets in developed nations. Clearly they overlap and can combine.

\section{B. Haves vs. Haves}

Vertical conflict — between the capital markets' haves and the have-nots is not the only political economy array here. There's a horizontal dimension as well, of conflict among the haves, one that comes in three major varieties: conflicts between capital owners, conflicts between large firm managers and capital markets, and conflicts between controlling shareholders and capital markets.

1. Capital markets' internal fissures, especially that of banks vs. stock market capitalism. If securities markets are weak, more capital will flow through the banking system. Deposit banks have an interest in keeping securities markets weak, unless they can control securities flows themselves. The interests seek to protect themselves using the political realm. Macey \& Miller (1991) showed that in the United States deposit banks often lobbied for blue sky laws that raised the costs of stock sales.

Small banks have an interest in stifling competition from big banks. In the United States, this historically took the primary form of small banks inducing political decision-makers to bar the large, money-center banks from entering the

\footnotetext{
${ }^{2}$ Weymouth \& Broz (2008).
} 
small banks' local market. The result was that the small banks had local monopolies or oligopolies, while large banks lacked a nation-wide deposit base. Roe (1994) emphasizes this feature of nineteenth century (and most of the twentieth century) American financial history, particularly when the power of local bankers combined with populist opinion that militated against large, centralized financial institutions. With even the largest banks relatively small in relation to the economy, banks could not readily provide the financing for continent-spanning industries at the end of the nineteenth century. The consequence was that the demand and need for securities markets was enhanced.

Intra-capital-market tactical conflict can have unexpected, but profound, outcomes, as Langevoort (1987) shows. During the 1933 banking crisis, larger money center banks sought to dissuade Congress from enacting deposit insurance, because they thought they would end up paying disproportionately for the insurance and, without the insurance, deposits would run off from smaller, country banks to the larger, more stable money center banks. (Yes, there was a time when such large, money center banks were seen as the most stable in the American economy.) Because they knew that Congress would insist on doing something, they suggested and supported splitting investment from commercial banking (as they were not making much money in the securities business anyway). By so suggesting, they hoped to dissuade Congress from mandating deposit insurance. Congress did sever investment from commercial banking via the famous GlassSteagall Act of 1933, as the large banks suggested. But Congress also decided nevertheless to insure banks deposits, which the large money center banks had opposed.

2. Managers vs. capital markets. Managers of large diffusely-owned firms have reason to disrupt their shareholders' capacity to aggregate their stock ownership. Although they do not necessarily own capital themselves, they control it and they seek to maintain their control over capital. They seek laws that impede or bar hostile takeovers. They seek rules that make it costly for shareholders to take large, active positions. They seek proxy contest rules that make it hard for shareholders to elect directors other than those that incumbent managers support. (Corporate election contests are costly. Stockholder votes need to be solicited, corporate election contest rules have to be complied with, and publicity needs to be sought. The firm pays for the incumbents' nominees, but insurgents generally pay their own costs, although any gains they bring about accrue to all shareholders. Free rider problems abound, deterring otherwise valuable contests.) These conflicts could be characterized alternatively as politically powerful haves (the managers) moving value into their hands and away from economically well-to-do haves (capital owners) who are less politically powerful.

These managerial efforts have been significant in the United States historically and continue to be central even today. Managers have successfully opposed proposals in this past decade to allow shareholders easy access to the firm's proxy statement, which would allow dissidents to more easily elect directors, although the issue remains on the SEC's agenda. Prior outbreaks of the shareholder access proposal in the United States, starting in the 1940s, also died after managers successfully opposed the proposals. There's a considerable 
literature on managerial-shareholder conflict in the United States. ${ }^{3}$ The literature on the spillover of managerial preferences and authority into the political sphere is thinner, although efforts can be found in Roe (1990, 1993), Grundfest (1990), and Bebchuk \& Neeman (2010).

Managers of fully stockholder-controlled firms could not readily seek such rules initially, as their controlling shareholders would be unhappy with such managerial lobbying. But once ownership became diffuse, perhaps because of the combined impact of American populism and the interests of small-town bankers in the nineteenth century, managers could more readily engage in such political action, free from shareholder veto.

3. Controlling shareholders vs. capital markets. Controlling shareholders have reason to maintain rules that allow them to shift value to themselves. Corporate rules affect the private benefits of control — such as the ease with which small shareholders can reverse related-party transactions between the firm and the controlling insiders, and the ease by which controlling shareholders can squeeze out minority stockholders at an unfair price. Once a player controls a public firm, it has an interest in maintaining (or expanding) its capacity to shift value to itself. ${ }^{4}$ This feature seems to have been important in several western European nations in recent decades. ${ }^{5}$

\section{Capital Markets and Financial Politics in the DeVeloping WORLD}

\section{A. Rudiments without Government Institutions}

Development authorities often focus on bolstering institutions that promote financial markets, in the belief that better financial markets will lead to economic development. They seek to develop superior corporate laws, better securities laws, and better courts and other institutions to enforce financial and other contracts. These efforts are appropriate, but the initial conditions needed historically for financial markets have been simple, with political economy conditions central. If the developing nation is sufficiently stable politically and socially, the first steps for financial markets institutions can be taken, and often have been taken, with limited government action. Thereafter, as the financial markets develop, there will be interests that seek to institutionalize that development and push it to the next level — and who have the know-how to do so.

This sequence - first social and political stability, then financial market development, and then legal consolidation later - is illustrated in studies of the initial development of the planet's strongest securities markets. They all show a rather weak corporate institutional environment initially, but one embedded in a sufficiently stable environment so that reputational forces could propel initial, extra-legal financial market development. Related concepts of repeated games,

\footnotetext{
${ }^{3}$ E.g., Berle \& Means (1933), Jensen \& Meckling (1976).

${ }^{4}$ Bebchuk \& Roe (1999).

${ }^{5}$ Morck, ed. (2000) (concentrated ownership).
} 
with expectations of long time lines for the repeating, as generating mild but real institutional self-enforcement, are relevant here. ${ }^{6}$

Consider Bradford DeLong's (1991) famous piece on Morgan's directors. In an environment of weak corporate law, see Rock (2001), the Morgan firm put their partners on firms' boards, in order to offer their own reputation to protect shareholders from scurrilous or incompetent management. (And, it must be added, perhaps facilitating cartelization, through the Morgan partners sitting on boards of competitors.) Pernicious insider dealings, or undiscovered managerial incompetence, would cost the Morgan firm dearly, so they warranted (albeit weakly) that such nefarious or incompetent results would be unlikely to occur in the firms on whose boards they sat. Outside investors might not trust the firm, but they had more reason to trust the Morgan directors. Other investment banking firms presumably acted similarly.

Miwa and Ramseyer (2002) find an analogous reputational market at work in the nascent Japanese stock market of post-Meiji Restoration, late nineteenth century Japan. Firms sought directors with sterling reputations, to warrant to smaller stockholders that the firm had, and would continue to have, adequately fair and satisfactorily competent management. The reputational directors had a lot to lose socially and perhaps psychologically, so they cared what happened inside the firm. Franks, Mayer \& Rossi (2009) and Mayer (2008) demonstrate a similar process at work in Britain at the end of the nineteenth and early twentieth centuries. Reputations and repeat dealings supported a nascent stock market. Hardedged, government-facilitated legal institutions came later.

The point here is not that reputational structures are a panacea, obviating the need to build supportive institutions. Rather, the point is two-fold: a financial market can start developing without preexisting strong institutional support, but it needs a stable political and social environment that makes the reputational markets valuable (and possible) to build. Once a rudimentary capital market is in place, a constituency in the nation that would support more rigorous institutions to regulate and promote capital markets begins developing.

The steps toward more rigorous institutions do not need to lead immediately to "hard" law. Stock markets' enforcement, for example, can initially be built, again albeit weakly, by the financial players. They can punish miscreants by exclusion (such as by de-listing in stock market terms or breaking the miscreants' trading bench at medieval trading fairs, points made, respectively, by Mahoney (1997) and North and Weingast (1989)).

These private, exclusionary mechanisms were important in the development of American stock markets. ${ }^{7}$ But such private ordering is imperfect, as the punishments the private players can invoke - typically exclusion or a besmirched reputation - cannot reach the severity that public punishments can, via criminal penalties and fines. Still, the point persists that some sanctions can start before the public authorities act, as long as the political and social setting is sufficiently stable.

\footnotetext{
${ }^{6}$ Greif (2006: ch. 3 and 441-43), cf. Scott (1987).

${ }^{7}$ Mahoney (1997), Coffee (2001), Roe (2001).
} 
Presumably such private ordering mechanisms could come forth and be effective in other nations, including developing nations today. But for many nations without sufficient political stability, such reputational and private ordering institutions are difficult or impossible to start up. Hence, those seeking to promote capital markets should have reason to inquire into the sources of political stability, a subject I examine below.

\section{B. Elites’ Interests}

A nation's elites may have little interest in promoting financial markets. Two self-interested reasons could be in play. First, the elites may have satisfactory access to capital through, say, family banks or informal channels. Their grip on the polity may also allow them to stifle entry into banking, thereby keeping capital in the channels they already control. But a widespread, deep capital market could challenge the elite's monopoly status by facilitating upstart competitors' access to capital and, hence, increasing the upstarts' capacity to compete with the elites.

Rajan and Zingales (2003a) analyze this channel in several contexts, of both developing and developed nations, and show how trade openness affects a nation's elites' calculations. If the nation is open to trade, then the elites' underlying businesses must compete, simultaneously making efficient allocation of capital vitally important to them and making any suppression of competition with local upstarts less valuable (because international, cross-border competition will be intense anyway). Thus, Rajan and Zingales (2003b) conclude, in open-trade countries, elites would be less likely to oppose capital market development. Elites in closed countries would have greater incentives to suppress capital market development.

For developing nations, Acemoglu, Johnson \& Robinson (2001), Engerman \& Sokoloff (2002, 2005), and Engerman, Haber \& Sokoloff (2000) each indicate how land and agricultural conditions, settlement conditions, and factor endowments could affect early colonial structures so as to strengthen (or weaken) elites with repressive interests and capacities. Particularly where settlement conditions were difficult due to terrain or climate, or where plantation-style agriculture was most efficient, colonial conditions induced powerful, concentrated elites who had little need for either broad-based property rights or open opportunity societies. Those original conditions persist or they induced equalityimpeding institutions that persist to today. In other colonial settings, particularly where land, climate, and agriculture made European settlement easy and favored smaller, more widely-distributed and often individually-owned farms, colonization induced broad-based property rights, with weaker elites. These contrasting original settlement conditions then set the stage for equality-enhancing or equalityimpeding institutions, which in turn affected property rights and financial markets over the long run. Analyses of the same general genre can be found in Boix (2003: 45-46, 93) and Rodrik (1999). Cf. Olson (1984).

For Russia, Sonin (2003) and Hoff \& Stiglitz (2008) evaluate the political economy of the elites — there, the "oligarchs" - analogously. Property protection 
can be provided privately or publicly. The oligarchs were well-positioned to protect their property from other less powerful private players. Yet, they judged that publicly-provided property protection would facilitate competition from the less powerful, because the already-powerful can protect themselves adequately anyway, so they opposed stronger property rights. Hence, financial markets did not develop. (The oligarchs' opposition to stronger property rights, and the concomitant financial market development may have been short-sighted: the private, elite oligarchs were advantaged in property protection vis-à-vis less wellplaced private actors, but they did less well when pitted against emboldened public players when Putin came to power. Had stronger property protection and financial market depth been in place when the stronger state emerged, the government might have had more difficulty in suppressing the oligarchs in as many dimensions as it did.)

This elite suppression of competition explanation is important, although incomplete, because the elites that can shut down local financial markets can presumably also shut down open border trading markets. The explanation works well when trade barriers decline for an exogenous reason, such as European political goals of fostering a continent-wide economy in recent decades, in ways that overrode local interests.

Moreover, in a democracy, one must explain why the democratic polity accedes to the elites' interests. A plausible starting point is that the elites' interests coincide with those of others, making a politically-dominant coalition possible. A common example is that labor in the elites' industries also have reason to stifle product competition. The two may ally, with labor providing the democratic voting muscle, as Roe $(2001,2003)$ indicates. Consideration of more complex coalitions comes below. Here let us observe that movement to democracy, all else equal, should foster deeper capital markets, as elites have less weight in the nation's decision-making and, hence, their goal of suppressing competitive upstarts will be harder to attain. However, all else will not be equal when an oligarchy becomes a democracy, as the elites would be pressed then to form coalitions with broader voting groups, like labor. Corporatism and varieties of capitalism concepts may have contained this kind of coalition of elites with similarly-interested non-elites embedded in the conceptualization.

\section{Non-Elites’ Interests}

Non-elites in developing nations can affect property protection and capital markets. If they are living a subsistence life, then appropriating capital can make their lives much better in the short run. If they have weak prospects or are currently calorie-challenged, their immediate survival considerations should trump long-run development goals. Their long-run may be capital markets' short run.

And the converse problem of the haves seeking to suppress the rise of new competitors can occur. The have-nots can see property rights, such as investor protection, as protecting the haves. They could conclude that weaker investor 
protection would enable them to become the equivalent of squatters on the elites' financial assets.

These two dimensions could lead to complex calculations of self-interest: elites may want protection against financial squatters, but their offsetting desire to suppress new competition may weaken their interest in greater property protection. The have-nots may want to protect their meager property, and a few of the upwardly mobile may think they could enter the elite. But most conclude that investor protection protects the elites' capital from the have-nots' incursions. So they oppose strong property rights for capital.

\section{Political Stability}

Roe and Siegel (2010) advance a complementary idea - that financial markets cannot develop easily in severely unstable political environments. As Huntington (1968: 8) observes, "[a]uthority has to exist before it can be limited, and it is authority that is in scarce supply in those modernizing countries where government is at the mercy of alienated intellectuals [and] rambunctious colonels...." Roe and Siegel find that political instability robustly explains differing levels of financial development, even after controlling for trade openness and the level of economic development - and does so in both country-fixedeffects and instrumental variable regressions, and across multiple measures of instability and financial development. In an unstable society, investors' basic property rights cannot be secure, because they cannot be sure what the polity will look like over the life of their investments.

Moreover, a political economy literature plants instability's roots in inequality-perpetuating institutions and ethnic fractionalization. ${ }^{8}$ The first factor, economic inequality, fits tightly with explaining why investor protection doesn't develop in unstable environments: For the unstable polity to protect investors, it would have to protect the most favored elements in that polity. Yet that unstable polity is riven by contention over the division of wealth and income - i.e., whether the favored can keep their wealth. They use proxies for inequalityperpetuating institutions and social fractionalization of the type that Engerman and Sokoloff (2002) brought forward and that Easterly (2007) validated, as further evidence for the old idea that inequality induces instability. A developing nation needs to break the negative causal chain of inequality-to-instability-to-weakfinancial-development in order to position itself to develop its capital market.

\section{E. Inequality}

It bears separate emphasis that inequality is at the base of several of these theories. Severe inequality undermines political stability, but that political stability is foundational for financial market development privately and then publicly. Yet it may not be easy to reduce that inequality, not just for the obvious reason that those

\footnotetext{
${ }^{8}$ E.g., Alesina \& Perotti (1996), cf. Ayyagari et al. (2008).
} 
who lose from reducing inequality do not always support its reduction. Inequality may be due to the production technologies available in the economy; it may be endogenous to the polity itself.

Yet several of the world's most developed financial markets are in nations, like the United States, that have quite high Gini coefficients for the distribution of wealth and property. This characteristic deserves further inquiry.

1. Original conditions. Path dependence could explain this outcome. The nation's income and wealth distribution may have been substantially equal when financial markets first developed and then the nation accepted the inequality later. For the United States, this path dependence result is plausible, as American income and property distribution until the end of the nineteenth century was relatively flat. ${ }^{9}$ Financial markets started to develop during that era and, without a major political break, persisted. Preferences were not always pro-capital-market, but they sought to channel that market, not destroy it. Conversely, in countries that suffered a major political break, the distribution of income and wealth during the period in which the capital market was reconstructed could have profoundly influenced its subsequent shape.

A similar sequential process holds true for England. England was the locus of the first industrial revolution. Its severe labor shortage at the time and its energy abundance have been noted as foundations for the technological developments of the first industrial revolution. ${ }^{10}$ Less well-noted is that the higher wage rate that accompanies scarce labor would also mitigate inequality, thereby reducing potential political instability and, hence, giving capital market development an opening.

Engerman and Sokoloff (2002: 44-46, 63-83), as noted previously, offer a general structure of the political economy of property rights in the developing world, in which we can place rights in the capital market as a subset. If a colonizing power came to land areas best used for plantation-style crops or, say, mining activities using much unskilled labor, then the original political institutions would reflect the underlying land use characteristics. The colonists from the colonizing country had little reason to foster broad-based property rights, as they could protect themselves well enough. They had little reason to foster developing broad-based education and skills for their plantation workers, since the elites only needed unskilled labor. ${ }^{11}$ The consequence is that the nation early on, while still a colony, lacked widely-distributed property and had weak property protection institutions. Oppressive institutions persisted and capital markets had little role in future development. ${ }^{12}$

2. Conceptualizing economic inequality. A second characteristic is related but not identical. Politically-destabilizing inequality may not be a function of the raw ratio of wealth and income of the richest to that of the poorest. Rather it might

\footnotetext{
${ }^{9}$ Lindert (2006: 2-624).

${ }^{10}$ Allen (2009).

${ }^{11}$ Cf. Bobonis (2008).

${ }^{12}$ See also Acemoglu, Johnson \& Robinson (2001) and Engerman, Haber \& Sokoloff (2000). Cf. Glaeser (2006).
} 
be based on something more complex, which we can call a severity ratio. That is, we look at how close the poorest are to being unable to obtain (say) their 2000 calories per day. That is the denominator. The numerator is the excess (above 2000 calories per day) of the richest in that nation. ${ }^{13}$

In these terms, unlike in the conventional Gini concept, the United States is not all that severely unequal - even the bottom fifth can usually get their 2000 calories per day, unlike in other nations with sharp income inequality. In another polity, where the bottom fifth struggles to obtain only 1800 calories per day, the reconceptualized severity ratio could be quite high, even though the usual Gini calculation would consider the nation to be more equal than the United States.

3. Mapping inequality and equality onto race. Race, ethnicity, and religion can be central in a polity, particularly when wealth and income disparities cleave along racial or ethnic lines. If race and class map onto one another, that can make it easier for groups to demonize and dehumanize opposing groups and make a stable polity harder to achieve. Several studies have found such ethnic conflicts to be central to political instability. ${ }^{14}$

Race and ethnicity can have other effects, a result that makes analysis of their impact difficult. They can make it easier for capital markets to flourish by diverting conflict from economic to non-economic issues, thereby pushing conflict between haves and have-nots lower on the political agenda. If the polity cleaves along cultural or multiple identity lines that do not map onto distributional differences, those distributional differences can recede in political contentiousness. Dahl (1971), Benson (1961), Sombart (1906), and Schattsneider (1960) speak to this kind of issue in varying ways.

The distinction seems to be whether class and property-owning fault lines are also race and ethnicity lines. If yes, capital-market-debilitating conflict would seem likely to be enhanced; if not, then the polity may turn from economic conflict that could damage financial markets to social conflict.

\section{CONTEMPORARY AND HISTORICAL EXAMPLES}

In this Part, I expand upon several of these classifications, with an eye on political economy configurations around the developed world in recent decades.

\section{A. Contemporary}

1. Labor in Europe. After World War II, labor was particularly powerful in Europe, in ways that profoundly affected capital markets development. Capital markets institutions were poorly supported in terms of budgets and personnel for the capital markets' regulatory apparatus. ${ }^{15}$ With labor able to make strong claims on firms' cash flows, owners had more reason to stay in place and run the firm, or

\footnotetext{
${ }^{13}$ Williamson (2009).

${ }^{14}$ See Alesina et al. (2003); Easterly \& Levine (1997).

15 Jackson \& Roe (2009).
} 
keep a close watch on the managers, to have more of that cash directed to owners than to workers than weakly-monitored managers in capital markets would tend to direct. In the weakened international trading markets after the war, labor and owners had reason to unite to preserve their market position, keep out competition, and divide the spoils. ${ }^{16}$

2. Managers in the United States. Managers in the United States are a powerful interest group in making the rules governing corporate finance and capital markets. In the 1980s, for example, capital markets created the hostile takeover, which aggregated enough stock such that an outside firm or entrepreneur could acquire an established firm that had a diffusely-owned stock structure. (As is well-known, that diffuse ownership facilitated the growth of managerial agency costs, because managers lacked a day-to-day boss.)

In reaction to this agency-cost structure, outside firms and entrepreneurs would offer to buy up a target firm's stock, with a view to changing management policy or changing management itself. Yet managers were able to disrupt those hostile takeovers transactionally and politically. Transactionally, firms developed poison pills and staggered boards that made it costly for the outsider to buy up the target company's stock. Politically, managers, through their lobbying organizations such as Chambers of Commerce, the Business Roundtable, and, yes, the American Bar Association, obtained favorable laws through the political process - laws that validated and often added to these disruptions of the hostile takeover.

\section{B. Historical}

1. American populism. Populism can affect financial markets and institutions. Andrew Jackson's destruction in the 1830s of the Second Bank of the United States is the most famous example in American history. It was a seminal event in American financial political history, leaving the United States without a truly national banking system until the latter part of the twentieth century. The effect was to make securities markets more vital for the United States and to deny the United States even the rudiments of a central bank until the beginning of the twentieth century (or perhaps not until 1935). American capital markets could not develop via a nationwide banking system in the nineteenth and most of the twentieth centuries. Roe (1994) attributes a significant fraction of American differences from the rest of the world to the aftermath of Jackson's veto and the institutions developed to accommodate the resulting weak national banking system.

It could have gone the other way, as two early American Congresses and two American presidents chartered the first and second banks, making the decision to have a quasi-central bank a closer one than basic history books usually have it. Happenstance of political maneuvering was relevant, as an ambitious Henry Clay thought that early passage of a re-chartering would put Jackson on the defensive, forcing him to approve it, while at the same time the incumbent head of the Second Bank of the United States, Nicholas Biddle, proved to be politically clumsy. Yet

\footnotetext{
${ }^{16}$ Roe (2000, 2001, 2003).
} 
Clay underestimated both Jackson's resolve and the influence of smaller, weaker banks that preferred not to be challenged by the Second Bank's regulatory impulses. Jackson's veto and destruction of the Second Bank left the United States without a strong, national banking system.

Political economy and populist political impulses persisted, and institutions created by earlier preferences had staying power. After Jackson's 1830s destruction of the Bank, there were multiple efforts to facilitate a truly national banking system. However, these failed on the twin shoals of smaller banks' influence in Congress and populist opinion that did not want a truly national banking system.

During the Civil War, for example, the United States built institutions that were called national banks and that substantively received their charter from Washington. But these banks were not national in their operation, as they were permitted to operate from only a single physical location. This limit was challenged in the 1890s, as the Treasury proposed to allow nation-wide branching, but the challenge failed in Congress. It was challenged again in the 1920s and 1930s, but it was only mildly tweaked: branching of banks was still limited to a single state at most and, for many states, a smaller geographic profile.

Popular animus played a role in major banking and insurance legislation historically. Glass-Steagall's separation of investment and commercial banking, the Bank Holding Company Act of 1956's limits on bank activities (recall, for those familiar with the politicians of the time, Wright Patman's influence), and the major life insurance companies' lack of power to own common stock (due to the Armstrong investigation of 1906) all can be traced in major part to this popular animus. This left the United States with severe limits on national financial operations: a lack of a national banking system, banks without power to engage in commerce, and insurance companies without authority to own common stock. Although other nations have had some of these limits, few have had them all. Britain, for example, has had powerful insurers. Germany has had universal banks with substantial stock ownership and even more powerful control of their customers' votes. Japan has had nation-spanning banks with significant stock ownership.

2. German codetermination. German codetermination is a formal institution reflecting this shareholder-social democratic balance of power, vividly illustrating the political economy effects on core corporate institutions. To settle raw political conflict at several moments in the twentieth century, German social democracy led to laws mandating that labor be represented in firms' boardrooms, culminating in approximately parity representation for labor in 1976 for the nation's largest firms. Since unconstrained managers' agendas for continuance, size, and risk avoidance, see Jensen (1986), maps onto employees' own agendas for the same, an implicit, albeit rough, coalition can easily form between managers and employees. Shareholders will want to have a cohesive counter-coalition in the boardroom. Concentrated ownership is a primary way to concretize that counter-coalition. 


\section{Preference Aggregation and Combinatorics}

Thus far we have generally examined discrete interests and their preferences for and against various capital markets forms. Here in this Part, I examine, first, how coalitions can form, persist, and morph. Second, I examine the political institutions of preference aggregation and how they affect the political economy outcomes that in turn affect capital market results.

\section{A. Shifting Coalitions}

No one group may dominate the polity's capital market decisions. Coalitions may affect who wins and who loses, and capital markets' configuration.

1. Banks and labor in Europe. One of the more interesting instances of the formation of a capital-market-affecting coalition can be seen in post-World War II Western Europe. Perotti and von Thadden (2006) provide compelling argumentation and significant data to support the idea that western European polities in the post-World War II era had the equivalent of a banker-labor coalition that impeded capital market development.

The argument begins with the median voter theorem: in post-World War II western Europe, they posit that the median voter had strong human capital but little financial capital. As such, the median voter had little interest in promoting financial markets that could readily erode their human capital. Capital markets that demand the immediate imposition of new technologies as soon as they are available could readily erode the value of human capital skills tied to the old technologies. And, lacking much financial cushion, most voters were also very risk averse.

At the same time, banks — to the extent their creditors' interest dominated their other financial interests - were moderately risk averse (because the downside disproportionately affected their loans, while the upside benefited stockholders). Accordingly, banks that became primary corporate governance players had a risk-averse profile that fit well with the median voter's preferences. Labor with limited capital preferred banks to stock markets - and that is what they got. The median voter voted for bank-oriented capitalism. ${ }^{17}$

Moreover, if a decisive, median-voter middle class had seen its savings and wealth destroyed by the interwar inflation, it would plausibly put a premium on pension obligations guaranteed by the government. Then, as the government became the principal provider of pension and retirement funding, private pension funds, a major conduit for capital in the United States, would play a smaller role in that economy. ${ }^{18}$

One potential difficulty with this perspective is that the median voter in many nations lacks much financial capital, even in polities with stronger capital

\footnotetext{
${ }^{17}$ Or, analogously, their political parties made appropriate deals to support bank-oriented capitalism. Pagano \& Volpin (2005).

${ }^{18}$ See Perotti \& Schwienbacher (2009).
} 
markets. But it's plausible to recast the thesis in political coalition terms that I may later develop more deeply: In post-World War II Western Europe, labor was powerful, partly because much physical capital had been destroyed during the war (see below), despite that labor did not often provide the median voter. But in coalition with some savers, or with the banks themselves, labor and these capital interests could determine the political economy outcome for capital markets. ${ }^{19}$

2. Managers and populism. American managers indirectly benefited from American populism. A plausible view of the sequential development of American capital markets history is the following. In the 1890s, national enterprises became viable: railroads spanned the American continent, making the nation into a single market, and engineering economies of scale made large-scale production especially valuable. With American populism having facilitated a weak national banking system, mergers in that decade needed stock market financing. With stock market financing in place, ownership started separating from control. Once ownership separated from control, managers could become political actors in their own right, via their lobbying organizations such as the Business Roundtable, the National Association of Manufacturers, and Chambers of Commerce. Their interest was to preserve and enhance managerial authority, which they have accomplished.

3. Managers and labor in the United States. A similar American coalition could be found in the 1980s. Hostile takeovers made managers' lives considerably more difficult during that decade, as is well known. But they also disrupted workers' expectations in the firm, by putting their jobs at risk. Even if workers would not be left unemployed, they would find themselves in a disrupted work environment. Thus they opposed hostile takeovers.

The combination of managers and labor could be decisive in making for state anti-takeover law. When a Pennsylvania corporation was targeted for a hostile takeover, it sought strong antitakeover law from the Pennsylvania legislature. For many Pennsylvania legislators, voting for the legislation was easy, as both the Chamber of Commerce and the AFL-CIO supported the legislation. Roe (1993: 339), quotes a contemporary comment:

[The] lobbying effort is the product of teamwork between ... Pennsylvania labor unions and a coalition of over two dozen corporations working for the passage of the bill under the well-organized direction of the Pennsylvania Chamber of Business and Industry.

Constituency statutes, which allowed boards to consider labor interests when deciding whether to support or oppose a takeover, are a manifestation of this coalition.

4. Dominant stockholders and labor. Dominant stockholders could ally with labor. As we've seen, business elites often have an interest in suppressing financial

${ }^{19}$ It's also possible to recast the argument in property-owning terms. The relevant question would be whether the median voter owns property, not simply whether he or she owns financial property. If the median voter owns significant property - a house, a car — then he or she may support property rights generally, which include rights to financial property. 
markets, as upstarts need access to capital and, without strong financial markets, upstarts cannot get the capital to compete with incumbent elites. But this then begs the question of why, in a democracy, the polity would accede to the elites' interests.

Mistake is one possibility. Ideology is another. A coalition is a third: labor at the incumbent firms may get a slice of what would otherwise go to the incumbents, motivating labor at the business elites' firms to support the elites' interests because they coincide with their own. If labor obtains such a rent, it wants to suppress product market competition with their employer, suppress upstarts' access to new finance, and suppress open trade with foreign competitors - trade that would erode both labor's rents and those of the elite.

A sophisticated rendition of the multiple possible coalitions can be found in Gourevitch and Shinn (2005), who show how there are almost as many permutations as there are rich nations are in play. Labor power can dominate owners and managers, as in Sweden. Or owners and managers can coalesce to dominate workers, as in Korea. Or owners can dominate both, as in oligarchic nations. Or workers and owners can coalesce to dominate managers. Or workers and managers can dominate owners, as in corporatist states, such as Germany, Japan, and the Netherlands.

\section{B. Political Institutions and Preference Aggregation}

Particularly since Arrow's Impossibility Theorem, political scientists have examined mechanisms of preference aggregation in a polity, as these profoundly affect policy outcomes. As is well known, the impossibility theorem's conceptual power comes from voters having differently ordered preferences. When a choice between two of those options is presented, the voting result may differ from that which would result if the ordering of the choices had been otherwise.

1. Parliamentary vs. presidential systems: proportional representation and party-lists. Pagano \& Volpin (2005) adapt Persson \& Tabellini’s (2000, 2005) general inquiry into parliamentary systems, proportional representation, and presidential systems to corporate and capital markets. Party-list, proportional representation will enable a coalition among business owners and labor to enact rules that poorly protect capital providers (so that incumbent business owners benefit at the expense of outside investors) and that protect incumbent labor well. Decisions are not driven by the median voter, but by the way a dominant coalition is formed. Iversen \& Soskice (2006) argue that proportional representation structures facilitate center-left redistributive coalitions, while majoritarian, presidential, first-past-the-post systems facilitate center-right, low redistribution outcomes. In majoritarian systems, they indicate, the decisive middle class vote will side with the well-to-do for fear of being taxed by the poor; but in proportional representation systems, the middle class can ally with the poor to redistribute from the well-to-do while still maintaining enough influence in the middle-poor 
coalition to ensure that the middle-class are not themselves the target for redistribution.

Mueller (2006) shows further how first-past-the-post electoral systems, such as those in the United States, can affect corporate governance outcomes. In such political systems, a national interest group, such as labor, needs to persistently renew its capture of a working majority in the legislature, working district-bydistrict, legislator-by-legislator. But in a party-list system, the identity of the particular legislator is not vital to the interest group getting that legislator's vote: the legislator follows party discipline, thereby facilitating national deal-making in which national labor institutions could be quite influential. In systems with firstpast-the-post territorial elections, such as the United States, such national coalitions (and their concomitant influence) are harder to create and maintain. It's thus no accident that Tip O'Neill's famous aphorism - that all politics is local came from an American national politician, the locally-elected leader of the House of Representatives, a legislative body that is a collection of locally-elected representatives who make national policy.

Mechanisms for preference aggregation can have a profound impact on the ability of players to form coalitions and, consequently, on the influence they can exert on the development of capital markets.

2. American federalism: I. The organization of the American Congress is relevant here in another dimension as well. If all politics (in the United States) is local, local interests can determine national outcomes. One reason why all politics is local is the organization of the House of Representatives by districts. With representatives dependent on local interests for their election, the House was responsive historically to local bankers who wished to be shielded from out-ofdistrict competition. When technology was such that localized bricks-and-mortar banking was possible (i.e., before the era of automated teller machines), bankers presumably had the means and the motivation to influence on their local representatives' voting on whether to facilitate nationwide bank branching, a result that we've seen deeply affected American capital markets. The state-by-state organization of the Senate presumably could have had a similar, albeit weaker, impact.

Hence, one can see a structure-driven process: American political structure promoted local interests. When local banking was technologically possible, this local power overly emphasized local banking, making national banking markets impossible during the formative years of national industry. This meant large industrial firms had to raise their capital from disparate sources, facilitating a shift in authority inside the firm to managers.

3. American federalism: II, Delaware. American corporate and capital markets law is made in two principal jurisdictions: Delaware (via the law of corporate organization) and Washington (via the law covering securities regulation).

The federal organization of American corporate lawmaking has long been a focus of American corporate law academics, who have seen competition among states for corporate charters (and their resulting revenues) as a core driver in 
making corporate law, thereby applying Tiebout's (1956) insights on political jurisdictional mobility to the specifics of corporate lawmaking. Some thought the competition was "to the top" in making corporate law more efficient ${ }^{20}$ while others saw the competition as one to the bottom, by favoring the corporate players most central to the incorporation decision - managers, controlling shareholders, and their lawyers. ${ }^{21}$

Unlike other polities, the United States effectively allows the corporation to choose its own state of incorporation, regardless of where it does business in the United States; the corporation thus chooses its own governing law. (European integration may induce a similar structure, as recent EU Court of Justice decisions have facilitated corporations using the corporate law of a nation that is not its main place of business.)

Federal organization of the polity can affect capital markets. During the hostile takeover era, many states passed strong anti-takeover laws, making it transactionally more expensive for an outsider to buy up stock of a public firm. In the political balance were the following: Local managers did not want the hostile takeover to proceed. Local labor employed by the target company did not want the offer to proceed. While shareholders in the capital market presumably wanted the takeover to proceed, many of them were not local, because capital markets were national, or international. Hence, the balance favored in-state managerial and labor interests over capital market interests. ${ }^{22}$ Again, all politics is local.

4. American federalism: III, Delaware and Washington. The simultaneous state-federal structure of American corporate lawmaking can affect capital markets in another dimension, particularly if Delaware has room to maneuver, i.e., as long as state-to-state competition is not tightly binding. The interests that dominate in Delaware are not the same as those making corporate and securities law in Washington. Particularly during times of financial crisis or scandal, the populist input to weaken shareholder and financial strength in the corporation, or to punish managers who are seen as overly-compensated, is strong in Washington. That kind of input is weaker in Delaware, where the interests of managers and shareholders dominate, nearly to the exclusion of other interests and forces.

In areas that are of overlapping concern to national and Delaware lawmakers, the national and local polities interact in two major ways. First, Delaware may preemptively pass financial and corporate law that it might not have passed otherwise, to reduce the chances of federal intervention. It may do so out of self-preservation: If Delaware is way out of line with national sentiment, corporate law could move to Washington, which could replace Delaware lawmaking with national lawmaking, turning corporate law, like securities law, into national, congressionally-made law. Second, it may do so to protect its local interests: with first-mover advantages, Delaware may pass rules that go some but not all of the way to satisfying the national appetite. Doing so would allow it to preserve as

\footnotetext{
${ }^{20}$ Romano (1993), Winter (1977).

${ }^{21}$ Cary (1974), Bebchuk (1992). Kahan \& Kamar (2002) question how intense that state competition really is.

${ }^{22}$ E.g., Romano (1988), Roe (1993), Miller (1998).
} 
much autonomy for managers (or value for shareholders) as possible, by persuading the national player that enough had been done, so that the national players need not act. This is analogous to the process Spiller and Gely (2008) posited for the Supreme Court, by which the Court often decides in ways to diminish the chance of congressional action (by coming closer to congressional preferences than they would have otherwise), a process that Roe (2005) analyzed for Delaware-Washington interaction.

5. Corporatism and varieties of capitalism. Western European nations have been analyzed as corporatist systems for some time, with analysts viewing the economy as being largely governed by a tripartite of decision-makers: the government, peak labor associations, and employer representatives. The varieties of capitalism literature ${ }^{23}$ integrated this thinking into production characteristics. That literature argues that economies that depend on skilled labor tend not to have liquid stock markets, which would disrupt labor skills. Conversely, economies that depend less on labor with firm specific skills could handle capital markets' disruptions. While not exactly formal preference aggregation, these analyses do look at the informal institutions of coalition formation. Business leaders would want to be represented at the centralized decision-making institutions, thereby putting a thumb on the scale for close ownership and weaker capital markets as well.

6. Weak capital after World War II. Earlier in the paper, I offered the possibility that a defining feature of the political economy of American capital markets can be found in the destruction of the Second Bank of the United States, which left the United States without a nationwide banking system during the nineteenth century, when a continent-wide, nationwide industrial economy arose. The interests, ideologies, and institutions that resulted tended to reinforce themselves during times of crisis, and no crisis was so severe as to leave the economy flat, destroyed, and needing a fully new set of institutions.

Could there be a similar foundational political economy event for Western European and East Asian capital markets? I think there is, but as of now the possibility must be seen as a hypothesis, needing both theoretical and factual development.

The concept would be that after World War II enough political and economic institutions had been destroyed that a substantial new construction of those institutions took place. In those years, capital owners and labor interests sought to establish the rules of the game going forward from that time.

The twist arises from the following difficulty: We know that the rules of the game had a pro-labor and not a pro-capital tilt in the subsequent decades. But with capital scarce after World War II - the physical capital was, after all, largely destroyed - and with labor, especially skilled labor, relatively more abundant, the bargaining process in the economic arena should have favored the scarce resource in terms of favored rules and returns.

${ }^{23}$ Hall \& Soskice (2001). 
Yet, at least as far as the rules were concerned, the consensus is that the results went the other way. Labor markets, including wage rates and other benefits, were favored in the post-World War II decades.

The hypothesis I advance here and that should be developed elsewhere is a political economy one: When the bargaining for a new post-war understanding as to how to organize capital and labor markets, the pro-capital markets players were relatively weak in the political arena - weak relative both to labor at the time and to their more usual strength in influencing results. Their physical capital had largely been destroyed during the war; they had limited capacity to affect the politics of the time with campaign contributions, with lobbying, or otherwise when the foundational deals were made. Only later could they afford the time, money, and personnel for such efforts; then they made sure that they were represented at the peak bargaining of the corporatist model. By that later time, however, labor had acquired its post-war favored status.

\section{Geopolitics}

Geography and national political power can influence internal political economy. Geographic features of the last half of the twentieth century are relevant and can be quickly sketched out. Geographic features over time are more subtle, but can also be seen.

1. Countering the Soviet Union. The central geopolitical fact in Europe in the second half of the twentieth century was the looming presence of the Soviet Union. In the initial post-war elections, the communist party did quite well in France and Italy, making it important for centrist and conservative parties to co-opt the communist program, which they did. The result was policy that favored incumbent labor and that disfavored capital markets.

One can think of the geopolitics as lying along a continuum: in Eastern Europe, communists gained power and capital markets ended. In Western Europe, to stave off communist power, the political center had to adopt some of the left's program. For Japan, South Korea, and Taiwan, the relationship with China in the immediate post-war decades could well have brought similar domestic sensibilities into play.

2. European geography over the centuries. The state has been seen as stronger in Europe than in the United States. This view maps onto the view of state actors as their own interest group that seeks to diminish the power of private capital markets, as outlined in the initial section of this article. The strength of the European state could have first originated in European geography: the open eastwest plains of Europe meant that local security from invasion was always at issue and that vulnerability induced national militaries and strong states. Roe (2007). Post-war geopolitics reproduced the incentives for a strong state.

This geographic history would then contrast with that of the United States and Britain historically, and with that of Europe today. The United States and Britain were both separated from invaders by bodies of water - narrow but real in Britain's case and wide for the United States. That geographic separation meant 
that centralized, standing armies were not needed for national security, and the state could be weaker than otherwise, thereby leaving space for private capital markets to develop. And, today, after the fall of the Berlin Wall and a safer European geopolitical reality, one including European economic integration, the geopolitics of a centralized state for smaller European nations is historical, not current.

\section{Political Change: Rightward and Leftward Shifts over Time}

The left-right split's impact on financial markets, see Perotti and von Thadden (2006), Roe (2003), can be tested over time, but tests done thus far are not dispositive. That is, financial markets in the developed nations strengthened in the 1990s, even in nations with locally left-of-center governments. Several commentators have made much of this, see Botero et al. (2004).

This is an understandable misconception. ${ }^{24}$ The problem and its misconception can easily be conceptualized (and diagrammed, see Figure 2). Over time, the center of gravity in a polity can change, sometimes sharply: As an example, Tony Blair's election as prime minister in 1997 marked not the ascendancy of the hard left that long dominated the Labour Party, but rather the ascendancy of the moderating of the left as it tacked toward the center. Yet it would be coded as the ascent of a left-of-center government in the usual academic studies thus far. But capital markets may draw comfort from a tame left and flourish not because the left was in power but because the left had moved rightward. Brazil's experience with a market-friendly former union leader in the recent decade also illustrates the phenomenon and potential for a left-right attribution error.

Similarly, the Clinton presidency represented the American left-of-center, but that administration was as market-oriented as a right-tilting government in Western Europe in many eras.

\section{Local vs. Absolute}

${ }^{24}$ See Pinto, weymoun \& Eremenany (2010), Culpepper (2011).

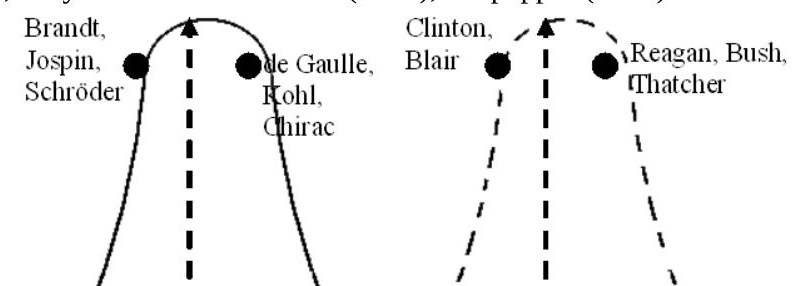


Indeed, in a pure median voter theory, the identity of the party in power makes no difference: it's the left-right location of the median voter that determines the polity's policies. Since some of the most substantial empirical work done thus far on left-right influence on capital markets suffers from this misconception, more work needs to be done here.

Eichengreen (2007: 333) explains why a left-of-center government can enact reforms that, in a prior decade, only a right-of-center government would have considered: “The German chancellor Gerhard Schröder's Agenda 2010 of labormarket reforms was motivated, in part, by the specter of German manufacturing moving east if steps were not taken to reduce labor costs."

And, again, preferences here seem as important as ongoing institutions in explaining capital markets outcomes. ${ }^{25}$

\section{INDETERMINACY, OVER-GENERALIZATION, AND LOCAL VARIATION}

Two characteristics can undermine the influence of the political economy academic agenda for understanding capital markets. First, although politics may well be decisive in determining capital markets' shape and extent, too many

${ }^{25}$ The rents-oriented version of the social democratic theory helps to explain Eichengreen's observation. Let's posit, again, that rents to labor and owners in key industries help to fuel the social democratic conventions demeaning capital markets, whose corrosive effects would erode rents to elites, see Rajan \& Zingales (2003a), and to the favored labor sectors that induce social democratic governments to oppose capital market development, see Roe (2001, 2003). As the rents erode, labor and its allies have fewer reasons to be wary of capital market development. Hence, their preferred policies would change.

Preferences and institutions interact. For example, many British corporate institutions developed early in the twentieth century, Franks, Mayer \& Rossi (2009), when Britain was a conservative polity. These institutions could have persisted, even when the polity moved leftward. The polity might not have allowed those institutions to arise in that era, but the extant interests (and institutions) could have been strong enough to resist severe destruction. 
political explanations are local: a particular coalition in this nation, the happenstance of deal-making in that nation. A narrative of national financial legislation may reveal the likely political economy story, but the explanation may not test well, because a testable characteristic may not repeat in a sufficient number of nations to run the required regressions. Consequently, only the most general of political economy theories may be susceptible to strong empirical analysis. National case studies via econometrically weak investigatory modes without enough data to run cross-country regressions could be how we see what explains capital markets depth, or lack of it. Armour and Lele (2009: 492-493) study Indian financial markets and investment protection in this manner, concluding with the primacy of political considerations: "In industries that were subject to planning, the dominant interest groups lobby for redistributive rules to maintain their protected status. By contrast, in sectors that were never subject to central planning, the dominant interest groups seek rules that allow markets to function more effectively. In short, the quality of investor protection and sectoral development have co-evolved on paths that have been to a large degree determined by past political choices."

A second problem afflicts a political economy approach. Often underlying our analysis is the goal of finding out what works for policy and recommending that policy's adoption. If we can find a simple rule or two that helps capital markets, or can find one that hinders them without ancillary benefit, then we can recommend which rules should be adopted and which should not be. But a political economy analysis does not yield us such strong, precise normative outputs. National politics is hard enough to understand, much less to influence with academic work.

But understanding the political economy inputs is still vital to normative analysis: If there's a menu of improvements for financial markets, but some will run into political economy problems, while others will not, then policymakers can choose accordingly, picking perhaps a less good policy, but one that will be politically more viable. International aid agencies may be particularly susceptible to ignoring political economy influences because they see it as illegitimate for them to seek political influence. But if the earlier focus on the centrality of political instability is correct, they can better choose how to allocate their aid and advice: Highly unstable polities are unlikely to benefit from even good rules; attempts to graft institutions for finance into such polities will be unlikely to "take.” Hence, the development agencies can channel their efforts into nations that already have sufficient stability for success to be possible. They can also choose among capital markets development policies that are more likely to stabilize than to destabilize the polity, presumably keeping distributional outcomes in mind.

\section{CONCLUSION}

Two fundamental fractures can cripple the politics of capitalism. One is the contest between the haves and the have-nots. Have-nots can conclude that they gain too little from capitalism, so they may expropriate capital from the haves. Capitalism may persist in form, but its productivity would be demolished, as 
savers will not save - i.e., will not create capital — because, in such polities, owners of physical and financial capital do not see their capital as safe. Instead, they will consume it, for if they do not, the have-nots will consume it. Alternatively, the haves may capture political institutions themselves and seek to put in place institutions that redistribute value to themselves. In the tension, capitalist institutions may not survive or, if they do survive, would fail to provide prosperity.

The second problem cuts the polity along another dimension: The capitalist haves may split and contest the polity among themselves. Those haves who have captured political institutions may seek to redistribute value away from other haves. The winners obtain rules that further their type of wealth. And with that enhanced wealth, they have both the strength and the motivation to preserve their position and to suppress competitive upstarts. If the institutions are roughly democratic, they will find it valuable to form alliances with voting masses, presumably starting with labor from their own industry.

The political problem of capitalism is to find institutions and preference distributions that keep the extent of such fissures and their costs low. No country succeeds in making them approach zero. Much that seems superficially inefficient to an economics-oriented analyst is a polity's effort to keep these fissures from rupturing the terrain.

These two problems arise in multiple dimensions in the economy, affecting welfare and social payments, antitrust policy, taxation, corporate law, income distribution, and financial markets. Many seemingly smaller problems in implementation of rules and laws are local manifestations of one of these two problems. I have for the most part analyzed these two basic problems in the politics of capitalism in terms of how they specifically affect financial markets and corporate structures. The issues may be more general.

We have made much headway in the past few decades in understanding how institutions persist through time. Institutions, though, are created. And institutions are also torn down and replaced. People and polities with preferences and interests create them, change them, and at times destroy them. Sometimes previouslycreated institutions can withstand a tidal wave from current preferences, sometimes they cannot. Sometimes preferences create new institutions that endure. Sometimes today's result can be predicted from the preexisting institutional framework; sometimes currently-created preferences that emerge from an economic or political crisis determine today's result. The political economy of capital markets well illustrates this interaction between preferences and institutions. Only when we understand how preferences for and against capital markets interact with institutions in the political economy will we understand the shape and extent of the capital market. Today's preferences when effective and dominant in the political arena become tomorrow's governing institutions.

\section{References}


Acemoglu, Daron, Simon Johnson, and James A. Robinson, 2001. The Colonial Origins of Comparative Development: An Empirical Investigation, American Economic Review 91, 1369-1401.

Alesina, Alberto, and Roberto Perotti, 1996. Income Distribution, Political Instability, and Investment, European Economic Review 40, 1203-1228.

Alesina, Alberto, Arnaud Devleeschauwer, William Easterly, Sergio Kurlat, and Romain Wacziarg, 2003. Fractionalization, Journal of Economic Growth 8, 155-94.

Allen, Robert, 2009. The British Industrial Revolution in Global Perspective (Cambridge: Cambridge University Press).

Armour, John, and Priya Lele, 2009. Law, Finance, and Politics: The Case of India, Law \& Society Review 43, 491-526.

Ayyagari, Meghana, Asli Demirgüç-Kunt, and Vojislawv Maksimovic, 2008. How Well Do Institutional Theories Explain Firms' Perceptions of Property Rights?, Review of Financial Studies 21, 1833-1871.

Bebchuk, Lucian, 1992. Federalism and the Corporation: The Desirable Limits on State Competition in Corporate Law, Harvard Law Review 105, 1435-1510.

Bebchuk, Lucian, and Zvika Neeson, 2010. Investor protection and interest group politics, Review of Financial Studies 23, 939-961.

Bebchuk, Lucian and Mark Roe, 1999. A Theory of Path Dependence in Corporate Ownership and Governance, Stanford Law Review 52, 127-170.

Benson, Lee, 1961. The Concept of Jacksonian Democracy: New York as a Test Case (Princeton: Princeton University Press).

Berle, Adolf, and Gardiner Means, 1933. The Modern Corporation and Private Property (New York: Macmillan).

Bobonis, Gustavo J., 2008. Political Institutions, Labor Coercion, and Emergence of Public Schooling: Evidence from the $19^{\text {th }}$ Century Coffee Boom, Working Paper, University of Toronto.

Boix, Carles, 2003, Democracy and Redistribution (New York: Cambridge University Press).

Botero, Juan, Rafael Djankov, Rafael La Porta, Florencio Lopez-de-Silanes, and Andrei Shleifer, 2004. The Regulation of Labor, Quarterly Journal of Economics 119, 1339-1382.

Cary, William L., 1974. Federalism and Corporate Law: Reflections upon Delaware, Yale Law Journal 83, 663-705.

Coffee, John C., 2001. The Rise of Dispersed Ownership, Yale Law Journal 111, 1-82.

Collier, Paul, 1999, On the Economic Consequences of Civil War, Oxford Economic Papers 51, 168-183 , 2000. Economic Causes of Civil Conflict and their Implications for Policy, Working Paper, World Bank, June 15.

Culpepper, Pepper. 2011. Quiet Politics and Business Power: Corporate Control in Europe and Japan (New York: Cambridge University Press).

Dahl, Robert, 1971. Polyarchy: Participation and Opposition (New Haven: Yale University Press).

DeLong, J. Bradford, 1991. Did J.P. Morgan’s Men Add Value, in Peter Temin, ed.: Inside the Business Enterprise (Chicago: University of Chicago Press).

Douglas, William O., 1940. Democracy and Finance (New Haven: Yale University Press).

Easterly, William, 2007, Inequality does cause underdevelopment: insights from a new instrument, Journal of Development Economics 84, 755-776.

Easterly, William, and Ross Levine, 1997, Africa's Growth Tragedy: Policies and Ethnic Divisions, Quarterly Journal of Economics 62, 1203-1250. 
Eichengreen, Barry. 2007. The European Economy Since 1945: Coordinated Capitalism and Beyond (Princeton: Princeton University Press).

Engerman, Stanley L., and Kenneth L. Sokoloff, 2002, Factor Endowments, Inequality, and Paths of Development Among New World Economies, Economia 3, 41-109. 2005, Institutional and Non-Institutional Explanations of Economic Differences, in Claude Ménard and Mary M. Shirley, eds.: Handbook of New Institutional Economics 639-665 (New York: Springer).

Engerman, Stanley L., Stephen H. Haber, and Kenneth L. Sokoloff, 2000. Inequality, Institutions and Differential Paths of Growth Among New World Economies, in Claude Ménard, ed.: Institutions, Contracts and Organizations: Perspectives from New Institutional Economics 108-134 (Northampton: Edward Elgar).

Franks, Julian, Colin Mayer, and Stefano Rossi, 2009. Ownership: Evolution and Regulation, Journal of Financial Studies 22, 4009-4056.

Glaeser, Edward, 2006. Inequality, in Barry Weingast and Donald Wittman, eds.: Oxford Handbook of Political Economy 624-641 (New York: Oxford University Press).

Gourevitch, Peter, and James Shinn, 2005. Political Power and Corporate Control: The New Global Politics of Corporate Governance (Princeton: Princeton University Press).

Greif, Avner. 2006. Institutions and the Path to the Modern Economy: Lessons from Medieval Trade (New York: Cambridge University Press).

Grundfest, Joseph, 1990. Subordination of American Capital, Journal of Financial Economics 27, 89-114.

Hall, Peter A., and David Soskice, eds., 2001. Varieties of Capitalism: The Institutional Foundations of Comparative Advantage (New York: Oxford University Press).

Hoff, Karla and Joseph E. Stiglitz, 2008. Exiting a Lawless State, Economic Journal. 118, 1474-1497.

Huntington, Samuel P., 1968. Political Order in Changing Societies (New Haven: Yale University Press).

Iversen, Torben and David Soskice, 2006. Electoral Institutions, Parties and the Politics of Coalitions: Why Some Democracies Redistribute More Than Others, American Political Science Review 100, 165-181.

Jackson, Howell E. and Mark J. Roe, 2009. Public and Private Enforcement of Securities Laws: Resource-Based Evidence, Journal of Financial Economics 93, 207-238.

Jensen, Michael, 1986. Agency Costs of Free Cash Flow, Corporate Finance, and Takeovers, American Economic Review 76, 323-329.

Jensen, Michael, and William Meckling, 1976. Theory of the Firm: Managerial Behavior, Agency Costs and Ownership Structure, Journal of Financial Economics 3, 305360.

Kahan, Marcel, and Ehud Kamar, 2002. The Myth of State Competition in Corporate Law, Stanford Law Review 55, 679-749.

Langevoort, Donald, 1987. Statutory Obsolescence and the Judicial Process: The Revisionist Role of the Courts in Federal Banking Regulation, Michigan Law Review 85, 672-733.

Lindert, Peter, 2006. Economic Inequality and Poverty, in Historical Statistics of the United States (Susan B. Carter et al., eds.) (Cambridge: Cambridge University Press).

Macey, Jonathan, and Geoffrey Miller, 1991. Origin of the Blue Sky Laws, Texas Law Review 70, 347-397.

Mahoney, Paul, 1997. The Exchange as Regulator, Virginia Law Review 83, 1453-1500.

Mayer, Colin, 2008. Trust in Financial Markets, European Financial Management 14, 617632. 
Miller, Geoffrey, 1998. Political Structure and Corporate Governance: Some Points of Contrast Between the United States and England, Columbia Business Law Review 51-78.

Miwa, Yoshiro, and Mark Ramseyer, 2002. The Value of Prominent Directors: Corporate Governance and Bank Access in Transitional Japan, Journal of Legal Studies 31, 273-301.

Morck, Randall, ed., 2000. Concentrated Corporate Ownership (Chicago: University of Chicago Press).

Mueller, Dennis, 2006. The Economics and Politics of Corporate Governance, in Guido Ferrarini and Eddy Wymeersch, eds.: Investor Protection in Europe: Corporate Law Making, the MiFID and Beyond 3-30 (Oxford: Oxford University Press).

North, Douglass, 1990. Institutions, Institutional Change, and Economic Performance (Cambridge: Cambridge University Press).

North, Douglass and Barry Weingast, 1989. Constitutions and Commitment: The Evolution of Institutions Governing Public Choice in Seventeenth-Century England, Journal of Economic History 4, 803-832.

Olson, Mancur, 1984. The Rise and Decline of Nations: Economic Growth, Stagflation, and Social Rigidities (New Haven: Yale University Press).

Pagano, Marco and Paolo Volpin, 2005. The Political Economy of Corporate Governance, American Economic Review 95, 1005-1030.

Perotti, Enrico C., and Armin Schwienbacher, 2007. The Political Origin of Pension Funding, Tinbergen Institute Discussion Paper.

Perotti, Enrico C., and Ernst-Ludwig von Thadden, 2006. The Political Economy of Corporate Control and Labor Rents, Journal of Political Economy 114, 145-174.

Persson Torsten, and Guido Tabellini, 2005. The Economic Effect of Constitutions (Cambridge: MIT Press). 2000. Political Economics (Cambridge: MIT Press).

Pinto, Pablo, Stephen Weymouth, and Peter Gourevitch, 2010. The Politics of Stock Market Development, Review of International Political Economy 17, 378-409.

Rajan, Raghuram and Luigi Zingales, 2003a. The Great Reversals: The Politics of Financial Development in the Twentieth Century, Journal of Financial Economics 69, 5-50.

2003b, Saving Capitalism from the Capitalists (New York: Crown).

Rock, Edward, 2001. Encountering the Scarlet Woman of Wall Street, Theoretical Inquiries in Law 2, 237-264.

Rodrik, Dani, 1999. Where Did All the Growth Go? - External Shocks, Social Conflict, and Growth Collapses, Journal of Economic Growth 4, 385-412.

Roe, Mark J., 2007. Juries and the political economy of legal origin, Journal of Comparative Economics 35: 294-308.

, 2005. Delaware’s Politics, Harvard Law Review 118, 2491-2543.

2003. Political Determinants of Corporate Governance (Oxford: Oxford University Press).

, 2001. Rents and Their Corporate Consequences, Stanford Law Review 53, 1463-1494.

, 2000. Political Preconditions to Separating Ownership from Corporate Control, Stanford Law Review 53, 539-606. , 1994. Strong Managers, Weak Owners: The Political Roots of American Corporate Finance (Princeton: Princeton University Press). , 1993. Takeover Politics, in The Deal Decade 321-352 (Margaret Blair ed.)

(Washington: Brookings). 
, 1990. Political and Legal Restraints on Corporate Control, Journal of Financial Economics 27, 7-41.

Roe, Mark J., and Jordan Siegel, 2010. Political Instability: Effects on Financial Development, Roots in the Severity of Economic Inequality, SSRN working paper, available at http://ssrn.com/abstract=963214.

Romano, Roberta, 1988. The Future of Hostile Takeovers: Legislation and Public Opinion, University of Cincinnati Law Review 57, 457-506. Press). , 1993. The Genius of American Corporate Law (Washington, D.C.: AEI

Rousseau, Peter L., and Richard Sylla, 2006. Financial revolutions and economic growth, Explorations in Economic History 43, 1-12.

Schattsneider, E. E., 1960. The Semisovereign People: A Realist's View of Democracy in America (New York: Holt, Rinehart and Winston).

Scott, Robert E., 1987. Conflict and Cooperation in Long-Term Contracts, California Law Review 75, 2005-2054.

Skocpol, Theda, 1979. States and Social Revolutions: A Comparative Analysis of France, Russia and China (New York: Cambridge University Press).

Sombart, Werner. 1906 (1976). Why is there no Socialism in the United States? (Hocking, Patricia and C.T. Husbands, trans.) (New York: Int'l Arts and Sciences Press).

Sonin, Konstantin, 2003. Why the Rich May Favor Poor Protection of Property Rights, Journal of Comparative Economics 31, 715-731.

Spiller, Pablo, and Rafael Gely, 2008. Strategic Judicial Decision-Making, in Keith Whittington, Daniel Kelemen, and Gregory Caldeira, eds.: The Oxford Handbook of Law and Politics 34-45 (New York: Oxford University Press).

Stulz, René M., and Rohan Williamson, 2003. Culture, Openness, and Finance, Journal of Financial Economics 70, 313-349.

Sylla, Richard, Richard Tilly, and Gabriella Tortella, 1999. The State, the Financial Systems and Economic Modernization (Cambridge: Cambridge University Press).

Tiebout, Charles, 1956. A Pure Theory of Local Expenditures, Journal of Political Economy 64, 416-424.

Weymouth, Stephen, and J. Lawrence Broz, 2008. Partisanship versus Institutions as Determinants of Property Rights: Firm-Level Evidence, available at http://ssrn.com/abstract=1080259.

Williamson, Jeffrey, 2009. History Without Evidence: Latin American Inequality Since 1491, NBER Working Paper 14766, available at http://www.nber.org/ papers/w14766.

Winter, Ralph, 1977. State Law, Shareholder Protection, and the Theory of the Corporation, Journal of Legal Studies 6, 251-292. 